E3S Web of Conferences 1, 32009 (2013)

DOI: $10.1051 / \mathrm{e} 3$ sconf/20130132009

C) Owned by the authors, published by EDP Sciences, 2013

\title{
The dynamics of the content and migration of trace metals in aquatic ecosystems of Moldova
}

\author{
E. Zubcov ${ }^{1}$ and N. Zubcov ${ }^{2}$ \\ ${ }^{1}$ Laboratory of Hydrobiology and Ecotoxicology, Institute of Zoology, Academy of Sciences of Moldova, $\quad$ MD 2028, \\ Academiei st., 1, Republic of Moldova ecotox@yahoo. \\ ${ }^{2}$ Laboratory of Hydrobiology and Ecotoxicology, Institute of Zoology, Academy of Sciences of Moldova, $\quad$ MD 2028, \\ Academiei st., 1, Republic of Moldova natzubcov@mail.ru
}

\begin{abstract}
The current complex investigations, carried out according to well-established methods, allowed us to find the main patterns of the dynamics and migration of metals in the Dniester and Prut rivers, affected by natural and anthropogenic factors. Using a polyfactorial analysis approach, the quantitative effect of main factors (water debit, amount of suspended matter, volume of discharged wastewaters, amount of pesticides and fertilizers metals in water, suspended matter, silt sediments of rivers and reservoirs was revealed. The discharged industrial wastewaters contribute to freshwater pollution with $\mathrm{Ni}, \mathrm{Zn}, \mathrm{Cu}$, and $\mathrm{Cd}(\mathrm{r}>0.75) \mathrm{The}$ use of fertilizers and pesticides for agricultural purposes affects directly the dynamics of $\mathrm{Cu}, \mathrm{Zn}(\mathrm{r}=$ 0.74-0.92), and the pollution is intensified by the dismembered relief, the peculiarities of rainfall and intensive erosion processes. The Moldavian Thermal Power Plant polluted the water of cooling reservoir with V, Mo, $\mathrm{Ni}, \mathrm{Cd}$ and the water sediments - also with $\mathrm{Pb}, \mathrm{Zn}$ and $\mathrm{Cu}$, whose concentrations depend directly on the amount of burned fuel $(\mathrm{r}=0,76-0,97)$.
\end{abstract}

Key words: Heavy metals, distribution, migration, water, suspended matter, bottom sediments, pollution.

\section{Introduction}

The research of regularities of migration and distribution of chemical elements in the dynamic and rather complicated system "water-suspended matter-silt" is one of the main objectives of the theory on aquatic ecosystems functioning. Among the principal factors that determine the distribution and migration of trace elements in the system "water-suspended matter-bottom sediments" in the investigated ecosystems should be listed: highly dismembered relief, intensive erosion processes in the catchment area, pluvial torrential character of atmospheric precipitations, physical-chemical peculiarities of soils and rocks, type of hydrology, chemical properties of trace elements and, also, hydro technical building, application of chemicals, irrigation of agricultural fields and discharge of wastewaters.

\section{Materials and Methods}

The study area focused on the main freshwater ecosystems of Moldova. Dniester and Prut are the main rivers of Moldova and both originate in the Carpathian Mountains of Ukraine. The total length of Dniester River is $1352 \mathrm{~km}$, of which $657 \mathrm{~km}$ are within the borders of Moldova. The Prut River, which measures $976 \mathrm{~km}$ as total, including $695 \mathrm{~km}$ within the borders of Moldova, draining approximately $24 \%$ of the country, and forms Moldova's western border with Romania until it discharges into the Lower Danube. The Dubasari, Costesti- Stinca and Cuciurgan Reservoirs are three of main four water reservoirs of Moldova. The Dubasari Reservoir (surface area- 6750 ha, total volume- 485.5 $\mathrm{mln} \mathrm{m}^{3}$ ) was built on the Dniester River, the Costesti-Stinca Reservoir (surface area- 5900 ha, total volume- $735 \mathrm{mln}^{3}$ ) is placed on the Prut River, and the Cuciurgan Reservoir (surface area- 1730 ha, total volume- $73 \mathrm{mln} \mathrm{m}^{3}$ ) is situated in the Dniester River basin and plays the role of cooling reservoir for the Moldovan Thermal Power Plant.

The researches were initiated in the $1970 \mathrm{~s}$ and continue till nowadays. The samples of water, suspended matter and bottom sediments were collected from the Dniester and Prut Rivers, their tributaries, Dubasari, Costesti-Stinca and Cuciurgan Reservoirs. The samples were transported in polyethylene jars. In order to separate the dissolved forms of metals from suspended ones, the collected water samples were filtered by 0.45 -micron Millipore filter. Concentrations of metals were 
determined by direct absorption in air-acetylene flame using an atomic absorption spectrophotometer (AAS-3 "Carl Zeiss" company, Germany) as described elsewhere (Sapozhnikova et al. 2005). Since 2008 the metals have been determined by using a Perkin-Elmer atomic absorption spectrophotometer AAnalist 400 with the HGA 900 graphite furnace (Analytical Methods for Atomic Absorption Spectroscopy, 1996). Each analysis was performed in three replicates, and relative standard deviation was $1-2 \%$.

\section{Results and Discussion}

Zinc. The limits of variation of $\mathrm{Zn}$ content in the surface waters of Moldova are quite large: in water- from 5.6 to $4200 \mu \mathrm{g} / \mathrm{l}$, suspended matter- from 11 to $220 \mu \mathrm{g} / \mathrm{l}$. The highest contents were registered in the Bic Rivertributary of the Dniester River, and the lowest- in the Dubasari and Costesti-Stanca reservoirs. The $\mathrm{Zn}$ content increase continully both in water and suspended matter down along the course of Dniester and Prut Rivers; concomitantly, the ratio between suspended and dissolved forms increase continully in the favour of first. A positive correlation $(\mathrm{r}=0.75-0.83)$ between $\mathrm{Zn}$ content in water and suspended matter was observed, thus $\mathrm{Zn}$ content both in water and suspended matter is considerably higher during the period of spring water overflows than during low water levels.

For Dniester River a visible dependence of $\mathrm{Zn}$ content in water $\left(\mathrm{Zn}_{\mathrm{a}}, \mu \mathrm{g} / \mathrm{l}\right)$ and suspended matter $\left(\mathrm{Zn}_{\mathrm{s}}\right.$, $\mu \mathrm{g} / \mathrm{l})$ on water debit $\left(\mathrm{Q}, \mathrm{m}^{3} / \mathrm{s}\right)$ and content of suspended matter $(\mathrm{S}, \mathrm{mg} / \mathrm{l})$ was revealed, which is described by the following equations: $\mathrm{Zn}_{\mathrm{a}}=0.158 \cdot \mathrm{Q}+0.224 \cdot \mathrm{S}-14.4$, $\mathrm{R}=0.89, \mathrm{Zn}_{\mathrm{s}}=0.030 \cdot \mathrm{Q}+0.208 \cdot \mathrm{S}+20.2, \quad \mathrm{R}=0.92$.

Previously, the dependence of $\mathrm{Zn}$ content in the water of Dniester River on the used amount of chemicals containing $\mathrm{Zn}$ in agriculture ( $\mathrm{Z}, \mathrm{t} / \mathrm{an})$, volume of discharged wasterwaters in hydrografic network $(W, \mathrm{mln}$. $\left.\mathrm{m}^{3} / \mathrm{an}\right)$ and the river water debit $\left(Q, \mathrm{~m}^{3} / \mathrm{s}\right)$ (Zubcov, 2000) was established, being described by the regression equations: $\mathrm{Zn}=0.370 \cdot \mathrm{Q}+0.0897 \cdot \mathrm{Z}+0.007 \cdot \mathrm{W}, \mathrm{R}=0.99$

Copper. The dynamics of $\mathrm{Cu}$ content higly depends on the amount of chemicals with $\mathrm{Cu}$, which are used in plant protection against diseases and pests. These substances reach the water ecosystems with surface runoff, due to the pluvial torrential character of rainfall and highly dismembered relief of the teritory. The level of $\mathrm{Cu}$ content in the runoff from vineyards reaches 300 $\mu \mathrm{g} / \mathrm{l}$ in solution and $450 \mu \mathrm{g} / \mathrm{l}$ - in suspensions.

The $\mathrm{Cu}$ contents in water vary in the ranges of $0.2-88.6 \mu \mathrm{g} / \mathrm{l}$, and in suspended matter- of $2.0-270 \mu \mathrm{g} / \mathrm{l}$; the highest values are revealed in lower courses of Dniester and Prut Rivers, their tributaries and the lowestin the reservoirs.

The regularities of $\mathrm{Cu}$ distribution and migration are close to those for $\mathrm{Zn}$. The analyse of influence of an entire complex of factors- used amount of blue vitriol (V, $\mathrm{t} / \mathrm{an}$ ), volume of disharged wastewaters (W, $\mathrm{mln} \mathrm{m}^{3} / \mathrm{an}$ ), water debit $\left(\mathrm{Q}, \mathrm{m}^{3} / \mathrm{s}\right)$ on the dynamics of $\mathrm{Cu}$ content $(\mathrm{Cu}$, $\mu \mathrm{g} / \mathrm{l})$ in Dniester River allowed to establish the following dependence: $\mathrm{Cu}=0.0021 \cdot \mathrm{V}+0.02 \cdot \mathrm{Q}+0.068 \cdot \mathrm{W}-28.9, \mathrm{R}=$
0.89.The share of the suspended forms of $\mathrm{Cu}$ in the Dniester water is $39-80 \%$, in Prut water- $64-75 \%$.

Also, the dependence of $\mathrm{Cu}$ content in suspended matter on the amount of suspended matter in water $(\mathrm{S}$, $\mathrm{mg} / \mathrm{l})$ and water debit $\left(\mathrm{Q}, \mathrm{m}^{3} / \mathrm{s}\right)$ was obtained, which for Dniester River is described by the equation: $\mathrm{Cu}=0.069 \cdot \mathrm{S}$ $+0.099 \cdot \mathrm{Q}-16.4, \mathrm{R}=0.88$.

Nickel. The content of $\mathrm{Ni}$ in water varies in wide ranges. The highest contents (up to $250 \mu \mathrm{g} / \mathrm{l}$ ) are registered in Bic River downstream the Chisinau municipality, but the lowest - $(0,5 \mu \mathrm{g} / \mathrm{l})$ - in reservoirs. In river suspensions the $\mathrm{Ni}$ content is 3.8-9.5 times higher than in river water. In reservoirs the ratio between suspended $\mathrm{Ni}$ and dissolved one is equal to 0.8-5.2. In regard to the investigated ecosystems, it is important to mention that nowadays the Ni contents higher than $5 \mu \mathrm{g} / \mathrm{l}$ are registered in not more than $20 \%$ of water samples.

A dependence of Ni content in Dniester water on the water debit $\left(\mathrm{Q}, \mathrm{m}^{3} / \mathrm{s}\right)$, volum of discharged non-treated wastewaters (W, mln. $\mathrm{m}^{3} / \mathrm{an}$ ) and content of suspended matter in the water $(\mathrm{S}, \mathrm{mg} / \mathrm{l})$ was found: $\mathrm{Ni}=1.6-$ $0.001 \cdot \mathrm{Q}+0.080 \cdot \mathrm{W}+0.021 \cdot \mathrm{S}, \mathrm{R}=0.90$.

Regarding the Ni content in suspensions, an evident dependence on the water debit $\left(\mathrm{Q}, \mathrm{m}^{3} / \mathrm{s}\right)$ and amount of suspended matter in water $(\mathrm{S}, \mathrm{mg} / \mathrm{l})$ was demonstrated, which for Dniester River is described by the equation: $\mathrm{Ni}$ $=0.598 \cdot \mathrm{Q}+0.006 \cdot \mathrm{S}-11.3, \mathrm{R}=0.85$.

The dynamics of Ni in Cuciurgan Reservoir depends on the impact level of power plant.

Lead. The $\mathrm{Pb}$ contents in investigated waters are relatively low and in less than $15 \%$ of cases it exceed 5 $\mu \mathrm{g} / \mathrm{l}$. In suspended matter the ranges are much widerfrom 0,5 to $107 \mu \mathrm{g} / 1$. It is important to draw attention to the unusual high $\mathrm{Pb}$ contents $(38-107 \mu \mathrm{g} / \mathrm{l})$, which were registered many times on the whole course of Prut River downstream its confluence with Jijia River. The consequence of such concentration are supposed to be the result of wastewaters discharge into the river. Likewise, high $\mathrm{Pb}$ contents are observed in the Bic River in the area of Chisinau city both in water and suspended matter. In average, during the passage through the Chisinau city, the $\mathrm{Pb}$ content in the Bic water has been increasing 3-8 times (Zubcov, 2000).

The lowest $\mathrm{Pb}$ contents are registered in reservoirs. A clear dependence of $\mathrm{Pb}$ content in river waters on water debit was not revealed, although in more than $85 \%$ of samples, collected in the period of overflows and floods, the $\mathrm{Pb}$ content is higher than in those collected in period of low water levels.

For Bic River it was established the dependence of $\mathrm{Pb}$ content on the amount of discharged wastewaters (W, $\left.\mathrm{mln} \mathrm{m}^{3} / \mathrm{an}\right)$ and water debit $\left(\mathrm{Q}, \mathrm{m}^{3} / \mathrm{s}\right)$, which is described by the equation: $\mathrm{Pb}=0.5+0.583 \cdot \mathrm{Q}+1.067 \cdot \mathrm{W}, \mathrm{R}=0.98$.

Mainly, lead migrates in suspensions. The $\mathrm{Pb}$ content in the rivers and reservoirs suspensions is 10-33 times higher than in parental rocks and soils.

For Dniester River was established the dependence of $\mathrm{Pb}$ content in suspended matter on water debit $\left(\mathrm{Q}, \mathrm{m}^{3} / \mathrm{s}\right)$ and the amount of suspensions in water $(\mathrm{S}, \mathrm{mg} / \mathrm{l}): \mathrm{Pb}_{\mathrm{s}}=$ $0.027 \cdot \mathrm{Q}+0.058 \cdot \mathrm{S}-1.3, \mathrm{R}=0.95$.

It is important to emphasize that the highest $\mathrm{Pb}$ 
contents were registered after the Cernobal catastrophe in 1986 both in water ecosystems (up to $30 \mu \mathrm{g} / \mathrm{l}$ ) and water of torrential rains.

Cadmium. The range of Cd contents is the following: in the water and suspended matter of Dniester River- 0.45 $-6.95 \mu \mathrm{g} / \mathrm{l}$ and $0.25-4.25 \mu \mathrm{g} / \mathrm{l}$, respectively, of Prut River - 0.60-8.15 and 0.3-5.8 $\mu \mathrm{g} / 1$, of Dubasari Reservoir - 0.33-0.82 and 0.12-0.56 $\mu \mathrm{g} / 1$, of Costesti-Stinca $-0.22-0.95$ and $0.14-0.67 \mu \mathrm{g} / \mathrm{l}$, of cooling reservoir Cuciurgan 1.62-7.44 and 0.46-1.65 $\mu \mathrm{g} / \mathrm{l}$, respectively.

The highest contents were registered downstream industrial cities, e.g. quite high $\mathrm{Cd}$ contents (up to 24.6 $\mu \mathrm{g} / 1$ in water and up to $17.8 \mu \mathrm{g} / 1$ in suspended matter) were found in Bic River, in the area of Chisinau municipality.

Molibdenum and vanadium. These metals are called "satellites" of thermoelectric power plants, because, from one hand, the water thermofication contributes to the increase of migration capacity of Mo and V in water and, from other hand, these metals have been released during the burning both of solid and liquid fuel.

The dynamics of Mo and V content in the water of Cuciurgan cooling reservoir obviosly depends on the amount of fuel used by power plant $(r>0,9)$. The variation of Mo content in the reservoir water ranges 2.2-34.6 $\mu \mathrm{g} / 1$ and of $\mathrm{V}-3.0-30.2 \mu \mathrm{g} / \mathrm{l}$. Furthermore, in this region the level of Mo and $\mathrm{V}$ is relatively high in atmospheric precipitations: Mo- 1.5-9.9 $\mu \mathrm{g} / \mathrm{l}, \mathrm{V}-5.5-24.5$ $\mu \mathrm{g} / \mathrm{l}$.

The power plant have used mostly gaz during the last years and there was a tendency of decrease of Mo and $\mathrm{V}$ level in water, but such tendency has not been remarked for silts.

The ranges of Mo and $\mathrm{V}$ contents in the Dniester and Prut waters are relatively low $(0.4-2.8 \mu \mathrm{g} / \mathrm{l})$.

Aluminium. The lowest Al contents were remarked in reservoirs, and the highest-in tributaries. In addition, its main part, (in more than $80 \%$ of cases) migrates along with the suspended matter. Aluminium contents higher than $5 \mu \mathrm{g} / 1$ are registered in more than $10 \%$ of samples.

The dependence of $\mathrm{A} 1$ content in water $(\mathrm{Al}, \mu \mathrm{g} / \mathrm{l})$ on water debit $\left(\mathrm{Q}, \mathrm{m}^{3} / \mathrm{s}\right)$ and amount of suspended matter in the water $(\mathrm{S}, \mathrm{mg} / \mathrm{l})$ was highlighted, which in the case of Dniester River is described by the equation:

$\mathrm{Al}=0.012 \cdot \mathrm{Q}+0.023 \cdot \mathrm{S}-0.8, \mathrm{R}=0.84$.

An obvios influence of anthropogenic factors on the Al dynamics was not discovered.

Titanium. The dynamics of $\mathrm{Ti}$ is determined by natural factors. Over $95 \%$ of Ti migrates in suspensions; in less than $5 \%$ of samples $\mathrm{Ti}$ content in water exceed $5 \mu \mathrm{g} / 1$.

The dependence of Ti content in Dniester water ( $\mathrm{Ti}$, $\mu \mathrm{g} / \mathrm{l})$ and suspensions $\left(\mathrm{Ti}_{\mathrm{s}}, \mu \mathrm{g} / \mathrm{l}\right)$ on the water debit $(\mathrm{Q}$, $\mathrm{m}^{3} / \mathrm{s}$ ) and amount of suspended matter in water $(\mathrm{S}, \mathrm{mg} / \mathrm{l})$ is reproduced by the equations: $\mathrm{Ti}=0.029 \cdot \mathrm{Q}+0.018 \cdot \mathrm{S}$ $-1.1, \mathrm{R}=0,89, \mathrm{Ti}_{\mathrm{s}}=0.135 \cdot \mathrm{Q}+0.452 \cdot \mathrm{S}+2.7, \mathrm{R}=0,78$.

In this order of thoughts, the dynamics of trace elements in water and suspended matter is a function of physical-geographical and climatic patterns of catchment area and, also, the dynamics is a reflection of changes that occur in water bodies and their basins due to anthropogenic factors.

Bottom sediments are the most stable components of aquatic ecosystems, and they are a reflection of intrabasin physico-chemical and biological processes and play an important role in the circuit of chemical elements.

The content of $\mathrm{Zn}, \mathrm{Cu}, \mathrm{Pb}, \mathrm{Ni}, \mathrm{Mo}, \mathrm{V}$ in investigated bottom sediments is 2-7 times higher in comparison with soils. The highest values are observed in the Cuciurgan basin, and the lowest- in Dniester and Prut Rivers. In reservoirs bottom sediments the metals contents are higher than in rivers ones (Tab.1).

The current oxido-reduction conditions, $\mathrm{pH}$ level in the bottom layers of water in the investigated water bodies are favourable to the metals accumulation in the bottom sediments and make difficult the opposite process- their diffusion in water environment. But the decrease of oxido-reduction processes and $\mathrm{pH}$ value conduct to the release of trace elements in water, especially in the Cuciurgan cooling reservoir, where the mentioned phenomena is determined, also, by the thermic pollution.

Table 1 .Trace elements contents in the bottom sediments, $\mu \mathrm{g} / \mathrm{g}$ abs. dry mass

\begin{tabular}{|c|l|l|l|l|l|l|c|}
\hline \multirow{2}{*}{ Metals } & \multicolumn{2}{|c|}{ Dniester River } & \multicolumn{2}{c|}{ Dubasari Reservoir } & \multicolumn{3}{c|}{ Cuciurgan Reservoir (sectors) } \\
\cline { 2 - 8 } & $\begin{array}{c}\text { Camenca, } \\
\mathrm{n}=48\end{array}$ & $\begin{array}{c}\text { Maiachi, } \\
\mathrm{n}=28\end{array}$ & Rabnita, $\mathrm{n}=37$ & Cocieri, $\mathrm{n}=58$ & $\begin{array}{c}\text { upper, } \\
\mathrm{n}=68\end{array}$ & $\begin{array}{c}\text { medial, } \\
\mathrm{n}=82\end{array}$ & $\begin{array}{c}\text { lower, } \\
\mathrm{n}=76\end{array}$ \\
\hline $\mathrm{Pb}$ & $46.8 \pm 3.2$ & $50 . \pm 3.8$ & $56.9 \pm 4.7$ & $71.0 \pm 4.9$ & $69.3 \pm 4.1$ & $74.2 \pm 3.9$ & $62.2 \pm 2.8$ \\
\hline $\mathrm{Ti}$ & $1943 \pm 11.3$ & $2220 \pm 9.6$ & $2090 \pm 10.2$ & $2295 \pm 10.7$ & $2740 \pm 6.6$ & $1700 \pm 7.1$ & $2280 \pm 5.2$ \\
\hline $\mathrm{Ni}$ & $138 \pm 4.9$ & $146 \pm 5.2$ & $160 \pm 4.4$ & $188 \pm 5.1$ & $210 \pm 4.8$ & $204 \pm 6.8$ & $211 \pm 6.4$ \\
\hline $\mathrm{Mo}$ & $4.0 \pm 0.3$ & $4.8 \pm 0.7$ & $4.2 \pm 0.7$ & $5.9 \pm 0.9$ & $5.5 \pm 0.8$ & $13.6 \pm 1.2$ & $6.4 \pm 0.4$ \\
\hline $\mathrm{V}$ & $78.3 \pm 5.7$ & $80.7 \pm 4.9$ & $89.0 \pm 6.0$ & $118 \pm 7.7$ & $200 \pm 9.1$ & $142 \pm 5.9$ & $122 \pm 5.8$ \\
\hline $\mathrm{Cu}$ & $59.0 \pm 4.1$ & $78.0 \pm 4.9$ & $95.0 \pm 6.0$ & $176 \pm 7.1$ & $82.4 \pm 6.8$ & $177 \pm 9.7$ & $114 \pm 8.8$ \\
\hline $\mathrm{Zn}$ & $92.0 \pm 5.2$ & $96.0 \pm 5.8$ & $110 \pm 6.7$ & $148 \pm 6.4$ & $210 \pm 9.3$ & $202 \pm 8.7$ & $199 \pm 10.4$ \\
\hline
\end{tabular}




\section{Conclusion}

According to their concentrations in Dniester and Prut rivers, trace elements can be positioned in the following decreasing row: in the water- $\mathrm{Zn}>\mathrm{Cu}>\mathrm{Al}>\mathrm{Pb}>$ $\mathrm{Ni}>\mathrm{Mo}>\mathrm{Ti}, \mathrm{V}>\mathrm{Cd}$, in the suspensions $-\mathrm{Al}>\mathrm{Ti}>\mathrm{Zn}>\mathrm{Cu}>$ $\mathrm{Ni}>\mathrm{Pb}>\mathrm{V}>\mathrm{Mo}>\mathrm{Cd}$.

In comparison with parental rocks and soils of the region, the suspensions are considerably enriched with $\mathrm{Ni}$, $\mathrm{Pb}, \mathrm{Mo}, \mathrm{Cu}, \mathrm{Zn}$, beeing somehow poorer in Ti. The migration of trace elements in the system "watersuspended matter-bottom sediments" occur from up to down in the investigated ecosystems. Only in some cases (in Cuciurgan Reservoir) their diffusion from mud sediments to the water layer was registered. The high level of a range of micro-metals in mud sediments indicates the pollution of studied ecosystems with $\mathrm{Zn}, \mathrm{Cu}$, $\mathrm{Ni}$ and $\mathrm{Pb}$.

\section{Acknowledgements}

We would like to extend our appreciation to SCSTD,
Moldova (projects $\quad 06.411 .012 \mathrm{~F} \quad 11.817 .08 .15 \mathrm{~A}$ 11.832.08.04A).

\section{References}

Analytical Methods for Atomic Absorption Spectroscopy (1996). The Perkin-Elmer Corporation.

Sandor Z, Csengeri I, Oncsik MB, Alexis, MN, Zubcova E (2001) Trace metal levels in freshwater fish, sediment and water. Environ Sci Pollut Res 8: 265-268.

Sapozhnikova Y, Zubcov N, Hungerford S, Roy LA, Boicenco N, Zubcov E, Schlenk D (2005) Evaluation of pesticides and metals in fish of the Dniester River, Moldova. Chemosphere 60: 195 205.

Zubcova E.I. (2000) Biogeochemical migration patterns of heavy metals in the ecosystems of the Dniester and Prut rivers, Ecological problems of the Black Sea. Odessa: 55-59. 